\title{
Molecular orchestration of differentiation and function of regulatory $T$ cells
}

\author{
Li-Fan $\mathrm{Lu}^{2}$ and Alexander Rudensky \\ Howard Hughes Medical Institute and Immunology Program, Memorial Sloan-Kettering Cancer Center, New York, New York \\ 10065, USA
}

During the last decade, a unique mechanism of negative regulation of immune responses and inflammation by a dedicated population of so-called regulatory $T$ cells (Treg) has become a focus of intensive investigation. Through the discovery of transcription factor Foxp3 as a central molecular determinant of differentiation and function of Treg cells, the complex biology of these cells, including maintenance of immunological tolerance to "self" and regulation of immune responses to pathogens, commensals, and tumors, has become amenable to mechanistic studies. In this review, we discuss the molecular aspects of Treg cell lineage commitment, maintenance, and function.

The cornerstone of the adaptive immune system is the random generation of antigen-specific receptors in the process of somatic gene rearrangement. The immense diversity of this anticipatory recognition system provides an efficient counterbalance to rapidly evolving pathogens. Two major classes of lymphocytes, key cellular actors of the adaptive immune system, rely on different principles of antigen recognition: Immunoglobulin (Ig) receptors displayed by B lymphocytes recognize intact forms of antigens, whereas T-cell receptors (TCR) recognize antigens in the form of short peptides bound to the products of the major histocompatibility gene complex (MHC). The peptide-MHC complexes are displayed for T-cell recognition on the surface of antigen-presenting cells (APCs), among which dendritic cells (DCs) are unique in their ability to process and present antigens to $\mathrm{T}$ cells and to initiate the immune response. APC exploit the proteolytic machinery of intracellular protein turnover to generate antigenic peptides for T-cell recognition. MHC molecules sample the peptide content of main sites of intracellular proteolysis, the cytosol and the endocytic compartment, without discriminating between "self" and "foreign"-i.e., pathogen-derived-peptides. CD8 T cells recognize MHC class I molecules bound to peptides generated in the cytosol, whereas

[Keywords: $\mathrm{T}$ lymphocytes; tolerance; differentiation; transcriptional regulation]

Correspondence.

${ }^{1}$ E-MAIL rudenska@mskcc.org; FAX (646) 888-3160.

${ }^{2}$ E-MAIL lul@mskcc.org; FAX (646) 888-3160.

Article is online at http://www.genesdev.org/cgi/doi/10.1101/gad.1791009.
CD4 T cells recognize MHC class II molecules bound to peptides generated in the endosomes and lysosomes, although some important exceptions to this rule exist (Trombetta and Mellman 2005).

Sequence analyses of peptides displayed by MHC molecules revealed that the vast majority of peptides bound to MHC class I and class II molecules is derived from self-proteins. Furthermore, TCR have an intrinsic bias toward recognition of MHC molecules, and "tickling" of TCR through certain low-affinity interactions with self-peptide-MHC complexes displayed by thymic cortical epithelial cells is prerequisite for thymic T-cell precursors to pass a critical differentiation checkpoint dubbed positive selection. In the periphery, analogous interactions facilitate the long-term maintenance of mature CD4 and CD8 T cells and further shape TCR repertoire. Thus, this "self-referential" nature of T-cell recognition presents a tremendous problem of establishing T-cell tolerance to genome-encoded self-antigens, and to limiting reactivity to antigens derived from commensal microbiota, food, and environmental factors. In this review, we call "self" a sum of the aforementioned antigens, unrestrained reactivity to which causes diverse immune-mediated pathologies including autoimmunity, allergy, and asthma.

\section{Dominant and recessive tolerance}

Numerous mechanisms of tolerance described during the last several decades can be divided into two major groups. Cell-intrinsic mechanisms, also known as recessive tolerance, leading to physical elimination or functional inactivation of a given "self" reactive T-cell clone, operate both in the thymus and in the periphery and are likely responsible for neutralization of the majority of highaffinity T cells recognizing self. Immature CD4 and CD8 double-positive (DP) and single-positive (SP) thymocytes undergo apoptosis, or "negative selection," upon highaffinity TCR engagement by self-antigen displayed by thymic DCs and thymic medullary epithelial cells. Those self-reactive thymocytes that escape clonal deletion become "anergic" or incapable of efficient proliferation in response to a "self" antigen and differentiation into functional effector cytokine-producing or cytotoxic $\mathrm{T}$ cells (for review, see Starr et al. 2003). 
Beyond thymus, chronic engagement of TCR displayed by peripheral $\mathrm{T}$ cells by "self" antigens can also lead to activation-induced cell death or anergy induction. Peripheral anergy induction is reinforced by the two-signal requirement for initiation of the naive T-cell responses. This requirement is fulfilled upon simultaneous engagement of TCR and T-cell costimulatory receptor CD28 by cognate peptide-MHC complex and inducible CD28 ligands CD80 and CD86 displayed on the surface of APC (Lenschow et al. 1996). High levels of CD80 and CD86 expression are induced upon activation of a diverse set of dedicated sensors directly in response to microbial or viral products or indirectly by metabolic or biochemical changes they induce.

However, the recessive tolerance operating in a cellintrinsic manner and the two-signal requirement for the induction of productive immune response appear insufficient to counter the threat of immune-mediated pathology without dominant tolerance, a unique immunological mechanism that involves the suppression of "self"-reactivity by specialized cells acting in a dominant fashion. The initial experimental evidence in support of thymic generation of cells capable of preventing autoimmunity came from a surprising finding of spontaneous T-cell-dependent autoimmune lesions in a variety of organs observed in mice subjected to thymectomy on day 3 of life (d3Tx) (Nishizuka and Sakakura 1969; Sakaguchi et al. 1982; Bonomo et al. 1995; Asano et al. 1996) and tolerance observed in chicken-quail chimeras (Ohki et al. 1987). Since adoptive transfers of $T$ cells from euthymic mice prevented autoimmunity in $\mathrm{d} 3 \mathrm{Tx}$ mice, these early observations suggested paucity of $\mathrm{T}$ cells capable of preventing autoimmunity in neonatal mice and, thus, laid a foundation for the concept of dominant tolerance.

\section{$\mathrm{CD}^{+}{ }^{+} \mathrm{CD}^{+} \mathrm{T}$ cells as mediators of dominant tolerance}

Long-lasting labors to define the cell type-mediating dominant tolerance resulted in the landmark discovery of a subset of CD4 $\mathrm{T}$ cells, constitutively expressing high amounts of the interleukin-2 receptor $\alpha$-chain (CD25), as being highly enriched in suppressor activity (Sakaguchi et al. 1995). CD $25^{+} \mathrm{CD} 4^{+} \mathrm{T}$ cells, dubbed regulatory T cells or Treg cells, were shown to be able to prevent autoimmunity upon transfer into d3Tx mice. Their potent suppressive capacity has been further demonstrated in multiple experimental models of autoimmunity, transplant rejection, and tumor immunity (for reviews, see Shevach 2000; Fehervari and Sakaguchi 2004). These cells make up $\sim 10 \%-15 \%$ of lymph node and splenic CD4 T cells in mice and $\sim 2 \%$ of peripheral blood CD4 T cells in humans. In the thymus, a subset of $\mathrm{CD} 25^{+} \mathrm{CD} 4^{+} \mathrm{SP}$ thymocytes with suppressive activity is present, but these cells are inconspicuous within the first few days after birth in agreement with d3Tx experiments (Asano et al. 1996; Fontenot et al. 2005a). These results indicated that $\mathrm{CD} 25^{+}$Treg cells serve as mediators of dominant tolerance and that these cells differentiate in the thymus in a developmentally controlled manner. Although identification of CD25 allowed for functional analyses of
Treg cells isolated from nonimmune animals, its utility as a definitive Treg cell marker was limited due upregulation of CD25 in all activated T cells. The inability to discriminate between protective and inflammationpromoting cells during the immune response impeded further understanding of dominant tolerance, especially its mechanistic aspects. Moreover, it was proposed that Treg cells are only conventional activated CD4 T cells that down-modulate immune responses by competing for interleukin-2. Thus, a search for a specific molecular marker of Treg cells and a genetic mechanism underlying the differentiation and function of these cells ensued.

\section{Foxp3: a key to dominant tolerance}

The key to discovery of the genetic basis of dominant tolerance was provided by identification of mutations in $\mathrm{X}$-chromosome-encoded transcription factor Foxp3 in mice with a spontaneous scurfy mutation and in patients with the IPEX (immune dysregulation, polyendocrinopathy, enteropathy, X-linked) syndrome (Chatila et al. 2000; Bennett et al. 2001; Wildin et al. 2001). In both humans and mice, loss-of-function Foxp3 mutations result in a fatal early-onset T-cell-dependent autoimmunity manifested by diabetes, thyroiditis, hemolytic anemia, hyper-IgE syndrome, exfoliative dermatitis, splenomegaly, lymphadenopathy, and "cytokine storm" (for review, see Gambineri et al. 2003). Importantly, the disease affected only hemizygous Foxp3 mutant males. In contrast, heterozygous female carriers of Foxp 3 mutations were spared from the disease, suggesting that $\mathrm{T}$ cells expressing a wild-type Foxp3 allele were able to restrain activation of $\mathrm{T}$ cells (Godfrey et al. 1994). An implicit assumption in this line of reasoning - namely, that Foxp3 mutations do not affect random X-chromosome inactivation in T cells-was subsequently confirmed by analysis of Foxp3 reporter mice (Fontenot et al. 2005c; Gavin et al. 2007), as discussed below. This consideration along with systemic nature of immune inflammatory lesions affecting multiple tissues in Foxp3 mutant individuals prompted several groups to examine expression of Foxp3 in $\mathrm{CD} 25^{+} \mathrm{CD} 4^{+}$Treg cells in mice. These studies revealed that Foxp3 is expressed at a high level in $\mathrm{CD} 25^{+} \mathrm{CD} 4^{+}$ Treg cells, but it is not present in significant amounts in naïve $\mathrm{CD} 25^{-} \mathrm{CD} 4^{+} \mathrm{T}$ cells or in antigen-stimulated $\mathrm{CD} 4^{+}$ T cells, which acquired CD25 expression upon activation (Fontenot et al. 2003; Hori et al. 2003; Khattri et al. 2003). Analysis of Foxp3 knockout mice showed that T cells in these mice become activated very early after birth, whereas the numbers of $\mathrm{CD} 25^{+} \mathrm{CD} 4^{+}$thymocytes are significantly diminished. Although these experiments strongly suggested that Foxp3 is required for differentiation of Treg cells, a caveat remained that early-onset autoimmune disease and T-cell activation potentially adversely affected the size or properties of the CD25+ Treg cell subset. This caveat was addressed, however, by examination of $\mathrm{CD} 25^{+} \mathrm{CD} 4^{+}$cell populations in the thymus and peripheral lymphoid organs of mixed bone marrow chimeras lacking lymphoproliferative disease and immune-mediated tissue lesions. In these studies, 
only Foxp3-sufficient, but not Foxp3-deficient hematopoietic stem cells were able to give rise to $\mathrm{CD} 25^{+}$Treg cells upon reconstitution of lethally irradiated recipient mice with Foxp $3^{\text {null }}$ and allelically marked Foxp $3^{\text {wt }}$ bone marrow (Fontenot et al. 2003). These experiments showed an absolute requirement for Foxp3 for Treg differentiation in the thymus. Furthermore, forced expression of Foxp3 in peripheral CD25 ${ }^{-} \mathrm{CD} 4^{+} \mathrm{T}$ cells using retroviral expression vectors results in acquisition of CD25 expression and suppressor function (Fontenot et al. 2003; Hori et al. 2003). In addition, expression of a Foxp3 transgene confers suppressive properties to CD8 T cells (Khattri et al. 2003). Finally, Cre-mediated ablation of a conditional Foxp3 allele in mature Treg cells results in a loss over time of suppressor function and characteristic Treg surface markers (Williams and Rudensky 2007). Together, these studies showed that Foxp3 is essential for Treg differentiation and suppressor function. However, they did not answer the question as to whether Treg cell deficiency alone is responsible for the fatal disease in Foxp3-deficient mice and men, or Foxp3 function in other immune cell types or in nonhematopoietic cells contributes to the disease.

\section{Foxp3-expressing Treg cells are vital for immune homeostasis}

Analysis of Foxp3 reporter mice generated upon insertion into the Foxp3 locus of a DNA sequence encoding a GFPFoxp3 fusion protein or a GFP or RFP coding sequence equipped with an IRES showed a surprisingly restricted expression of Foxp3 protein expression to a subset of CD4 T cells (Fontenot et al. 2005c; Wan and Flavell 2005; Bettelli et al. 2006; Lin et al. 2007). In addition to the prevalent $\mathrm{CD} 25^{\mathrm{hi}}$ Foxp $3^{+} \mathrm{CD} 4^{+}$T-cell subset, some $\mathrm{CD} 4^{+} \mathrm{CD} 25^{-}$or $\mathrm{CD} 4^{+} \mathrm{CD} 25^{\text {lo }} \mathrm{T}$ cells also express Foxp3 (Fontenot et al. 2005c). The potent suppressive capacity of all Foxp $3^{+}$T-cell subsets and lack of detectable high amounts of Foxp3 expression in other hematopoietic cells or nonlymphoid tissues were consistent with the notion of a dedicated function of Foxp3 in Treg cell differentiation. Although low levels of Foxp3 expression outside the regulatory T-cell subset was reported (Zuo et al. 2007a,b), additional experimentation is needed to further confirm its physiologic significance.

Initial evidence that the paucity of Treg cells accounts for fatal autoimmunity resulting from the Foxp3 deficiency was provided by studies where adoptive transfers of Treg cells rescued disease in neonatal Foxp3-deficient mice (Fontenot et al. 2003). Furthermore, mice with the T-cell-specific and germline ablation of the Foxp3 gene were indistinguishable in the progression and severity of the autoimmune lesions (Fontenot et al. 2005c). In contrast, deletion of a conditional Foxp3 allele in thymic epithelial cells or DCs, which shape the repertoire of developing T-cell precursors, did not result in any discernable immune dysregulation or alteration in the T-cell differentiation (Liston et al. 2007; L Williams and A Rudensky, unpubl.). These genetic studies implicated deficiency of Foxp3 within the T-cell lineage as a cause of the disease. Importantly, Foxp3 gene inactivation did not affect the sensitivity and two-signal requirement for T-cell activation, levels of cytokine production, and clonal expansion in peripheral nonregulatory $\mathrm{T}$ cells (Fontenot et al. 2003, 2005c; Chen et al. 2005; Hsieh et al. 2006). These findings together with a failure to detect a cellintrinsic role for the Foxp3 gene in regulation of recessive tolerance pointed to a lack of Treg cells as the cause of the disease associated with Foxp3 deficiency (Fontenot et al. 2003, 2005c; Chen et al. 2005; Hsieh et al. 2006).

Notwithstanding breakthroughs that came from the analyses of Foxp3-deficient mice, the question remained whether Treg function is critical during the development of the immune system or after the immune system is fully developed. This major outstanding issue was addressed through the analysis of Foxp $3^{D T R}$ knock-in and Foxp3-DTR BAC transgenic mice harboring an "ablatable" Treg population (Kim et al. 2007; Lahl et al. 2007). Chronic ablation of Treg cells in adult healthy mice results in their death within $3 \mathrm{wk}$ and demonstrates that Treg cell-mediated suppression is indispensable for preventing immune pathology throughout the lifespan of normal mice (Kim et al. 2007).

Considering a central role for Foxp3 in Treg biology, analysis of regulation of Foxp3 expression in the thymus and periphery and of Foxp3-dependent transcriptional and functional programs provides a key to mechanistic understanding of differentiation of Treg cells and of suppression they mediate. Furthermore, restricted expression of Foxp3 in Treg cells allows for development of powerful tools for in vivo genetic manipulation of various aspects of Treg biology. In the remaining sections of this review, we focus on recent progress in studies of molecular determinants of Treg cell differentiation and function.

\section{Regulation of Foxp3 expression}

In addition to CD25, Treg cells are known to stably express high levels of two negative regulators of TCR signaling and T-cell activation CD5 and CTLA4 (for review, see Sakaguchi 2004). These observations suggested that Treg cells themselves might express TCR with an increased affinity for "self" peptide-MHC complexes as compared with conventional "nonregulatory" $\mathrm{T}$ cells and that TCR specificity might guide Treg cell differentiation. The latter notion was supported by observations that in mice where all $\mathrm{T}$ cells express a single transgene-encoded TCR specific for a self-protein, myelin basic protein $(\mathrm{MBP})$, a severe immune-mediated inflammatory disease allergic encephalomyelitis (EAE) commences (Lafaille et al. 1994). In contrast, mice expressing the very same TCR transgene, but capable of endogenous TCR gene rearrangement, were disease-free due to the presence of protective Treg cells expressing endogenous TCR chains. Furthermore, adoptive transfer of these cells prevented disease in mice with monoclonal MBP-specific T cells present (Olivares-Villagomez et al. 1998). A further support for an essential role of TCR signaling in Treg differentiation came from studies where transgenic TCR coexpressed with a transgene-encoded 
corresponding TCR ligand in the thymus or chronically exposed to TCR ligand in the periphery facilitated differentiation of Treg cells (Jordan et al. 2001; Apostolou et al. 2002). Numerous transcription factors activated downstream from TCR were implicated in regulation of Foxp3 at a transcriptional level. These factors, including NFAT, AP1, CREB, and ATF, were shown to bind to the promoter region or to an intronic Foxp3 element proposed to serve as an enhancer (Mantel et al. 2006; Kim and Leonard 2007). In addition, TCR-induced NF-кB pathway was implicated in Treg differentiation (Schmidt-Supprian et al. 2004; Gupta et al. 2008). Besides TCR, CD28 signals play a cell-intrinsic role in Treg cell generation and maintenance. This notion is supported by greatly reduced numbers of Foxp $3^{+}$thymocytes and peripheral T cells in the absence of CD28 or its ligands CD80 and CD86 (Salomon et al. 2000; Tai et al. 2005). However, molecular mechanisms of CD28 involvement in Foxp3 induction are not clear since in vitro studies showed that extended activation of Akt, a main target of the CD28 signaling pathway, impaired generation of Foxp $3^{+}$cells. Conversely, inhibition of PI3K activation and, therefore, of Akt activation facilitated Foxp3 induction (Haxhinasto et al. 2008; Sauer et al. 2008). These recent findings were in agreement with an earlier observation of a twofold increase in numbers of thymic Foxp $3^{+}$cells, yet significant decrease in splenic Foxp $3^{+}$Treg cells in mice harboring an inactive form of p1008 isoform of PI3K (Patton et al. 2006).

TCR/CD28 signals alone appear to be insufficient to induce Foxp3 expression. Indirect evidence in support of this notion came from observations of a delayed appearance of Foxp $3^{+}$thymocytes after birth, whereas CD $25^{+}$Foxp $3^{-}$CD4 SP thymocytes were readily detectable (Fontenot et al. 2005a). These findings were ascribed to a requirement of a second signal for Foxp3 induction likely emanating from the IL-2 receptor (Bayer et al. 2005; Fontenot et al. 2005a). Mice lacking IL-2 or IL-2R suffer from severe lymphoproliferative syndrome, and disease in the latter mice can be prevented upon provision of IL2R-sufficient Treg cells (Furtado et al. 2002; Malek et al. 2002). Two recent studies suggested a two-step model for Treg cell differentiation where, first, a TCR signal of an increased strength result in up-regulation of CD25, making Treg precursor competent to receive IL-2 signal, which then would induce Foxp3 expression in a STAT5dependent manner (Burchill et al. 2008; Lio and Hsieh 2008). A major role for IL-2 signaling in differentiation of Treg cells is emphasized by diminished numbers of Foxp $^{+}$cells in mice lacking IL-2 or IL-2R $\alpha$ or IL2R $\beta$ chains, the latter shared by IL2 and IL15 receptors. Furthermore, a complete lack of Foxp $3^{+}$cells is found in mice lacking common $\gamma$-chain $(\gamma \mathrm{c})$, a shared signaling subunit of all $\gamma \mathrm{c}$ family cytokines, or three key members of the family, IL-2, IL-15, and IL-7 (Fontenot et al. 2005b; Burchill et al. 2007; Malek et al. 2008; Vang et al. 2008). Since STAT5 is a key transcription factor activated downstream from $\gamma$ c cytokine signaling, it was proposed that STAT5 plays a pivotal role in induction of Foxp3 expression. STAT5-binding sites were found in the pro- moter and a conserved intronic region of the Foxp3 gene (Zorn et al. 2006; Burchill et al. 2007; Yao et al. 2007). Furthermore, in mice subjected to deletion of a conditional STAT5 allele at the DP stage of thymocyte differentiation, all Foxp $3^{+} \mathrm{T}$ cells originate from cells, which escaped deletion and continued to express STAT5, whereas STAT5-deficient Foxp $3^{+}$Treg cells are lacking (Burchill et al. 2007; Yao et al. 2007). Furthermore, constitutively active form of STAT5 leads to expansion of $\mathrm{CD} 25^{+} \mathrm{CD} 4^{+}$ Treg cells and is capable of rescue a defect in Treg cell generation in the absence of IL2, but also in the absence of CD28 (Burchill et al. 2003, 2008). Although in aggregate these studies appear to make a compelling case for an essential role for STAT5 in induction of Foxp3 gene expression, important caveats remain. Specifically, it is unknown as to what extent the recruitment of STAT5, and likewise of other transcription factors implicated in Foxp3 regulation so far, promotes Foxp3 locus opening, Foxp3 transcription, or survival of Foxp $3^{+}$Treg cells and their precursors and how nonredundant these functions might be. This concern is supported by observations of rescued differentiation of STAT5-deficient Foxp $3^{+}$Treg cells upon forced expression of Bcl2 and of a high level of Foxp3 expression upon ablation of STAT5 restricted to Treg cells (S Malin and M Busslinger, pers. comm.; Y Zheng and A Rudensky, unpubl.). Thus, further gene targeting and biochemical studies are needed to elucidate the cooperativity between, and redundancy of, numerous putative transcriptional regulators of Foxp3 expression recruited downstream from TCR and IL-2R as well as of additional signaling pathways; for example, Notch/RBP-J (Fig. 1; Samon et al. 2008; Ou-Yang et al. 2009).

In addition to IL- 2 and other $\gamma c$ cytokines, TGF- $\beta$, jointly with IL-2, was implicated in Foxp3 induction in peripheral $\mathrm{T}$ cells and more recently, in developing thymocytes (Chen et al. 2003; Zheng et al. 2004; Davidson et al. 2007; Horwitz et al. 2008; Liu et al. 2008). The latter notion is based on a profound, but transient, decrease in numbers of thymic Foxp $3^{+}$cells during the first week of life of mice subjected to thymocyte-specific TGF- $\beta$ receptor ablation (Liu et al. 2008). In agreement with this idea, a conserved intronic Smad/NFAT-binding Foxp3 element with an enhancer activity has been suggested to play a central role in induction of the Foxp3 expression in the thymus and in the periphery (Tone et al. 2008). It is possible, however, that during thymic differentiation TGF $\beta$ signaling affects survival of newly generated Foxp $3^{+}$thymocytes or their precursors rather then induction of Foxp3 expression. These findings imply distinct mechanistic requirements for thymic and peripheral Foxp3 induction and suggest distinct biological roles for Treg cells generated in the thymus and in the periphery (Fig. 1).

\section{Foxp3 expression in human $\mathrm{T}$ cells}

It is noteworthy that although Foxp3 is necessary for Treg development in both mice and humans, differences in Foxp3 expression patterns exist between these two species (Ziegler 2006). First, Foxp3 induction is observed 


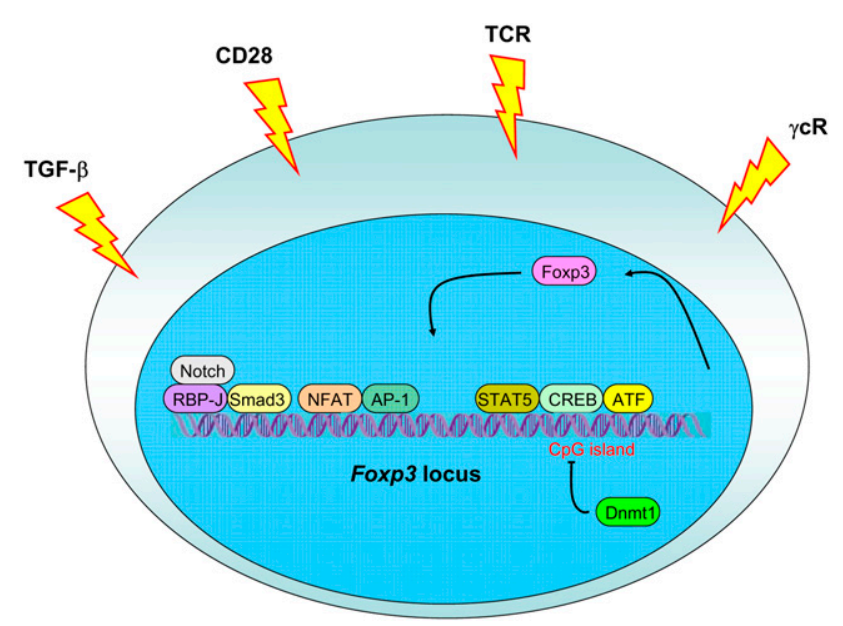

Figure 1. Regulation of Foxp3 expression. Foxp3 induction is dependent on an increased TCR signal strength combined with stimulation through CD28, and common $\gamma$ chain cytokine receptors. TGF- $\beta$ receptor signaling is required for differentiation of peripheral Treg cells, whereas its involvement in Treg differentiation in the thymus is subject of debate. As a consequence, corresponding downstream transcriptional factors are recruited to the Foxp3 locus leading to Foxp3 expression. Foxp3 itself is also suggested to stabilize its own expression. Moreover, complete demethylation of a CpG island within a conserved intronic noncoding Foxp3 element is also required for stable Foxp3 expression, whereas methylation of this CpG island by Dnmt1 in TGF- $\beta$-induced Treg cells likely results in a loss of Foxp3.

upon TCR stimulation of human T cells in the absence of exogenously supplied TGF- $\beta$ (Walker et al. 2003; Allan et al. 2005; Morgan et al. 2005; Gavin et al. 2006). However, this up-regulation is dependent on TGF- $\beta$ produced by activated $T$ cells and present in the serum (D Unutmaz, pers. comm.). Furthermore, Foxp3 up-regulation upon human T-cell activation is transient and results in levels of Foxp3 markedly lower than those in human Treg cells (Gavin et al. 2006; Wang et al. 2007). Consequently, this transient Foxp3 up-regulation does not result in acquisition of suppressor function in agreement with observations in mice that decreased Foxp3 expression in Treg cells results in impaired suppressive function (Wan and Flavell 2007). In addition, another difference in Foxp3 expression between humans and mice is generation of a human-specific Foxp3 splicing variant (Allan et al. 2005). This Foxp3 isoform is missing exon 2 and, therefore, lacks ability to bind and repress activity of ROR $\gamma \mathrm{t}$, a transcription factor critical for Th17 effector Tcell differentiation (L Zhou et al. 2008). Both splice variants are capable of imparting suppressor function to transduced human non-Treg cells, and their differential expression has not been reported so far. Thus, a physiologic role of the human-specific Foxp3 splice isoform remains to be defined.

\section{Determinants of stability of Foxp3 expression}

Adoptive transfers of Treg cells into Treg-deficient or lymphopenic recipients as well as studies employing Treg genetic tagging provide a compelling evidence of impressive Treg lineage stability (Komatsu et al. 2009; Y Rubstov and A Rudensky, unpubl.). Recent analyses of molecular features of TGF $\beta$-dependent induction of Foxp3 expression upon activation of peripheral $\mathrm{T}$ cells revealed important differences in epigenetic marks of the Foxp3 locus in these cells compared with ex vivo isolated Foxp $3^{+}$Treg cells. Specifically, it was found that in the latter cells an intronic $\mathrm{CpG}$ island within a conserved noncoding sequence element is demethylated consistent with the active Foxp3 locus, whereas it remains largely methylated in TGF 3 -induced Foxp $3^{+}$T cells as in Foxp3 ${ }^{-}$ T cells (Baron et al. 2007; Floess et al. 2007; Polansky et al. 2008). Instability of TGF- $\beta$-mediated Foxp3 induction in human and mouse $\mathrm{T}$ cells, and transient, relatively low level up-regulation of Foxp3 upon activation of human nonregulatory $\mathrm{T}$ cells is consistent with continuous methylation of this CpG-containing element and diminished CREB binding to a site overlapping with this element (Fig. 1; Kim and Leonard 2007). In support of this idea, pharmacologic inhibition of DNA methyltransferase activity and knocking down or ablating Dnmt1 gene markedly increase efficiency of induction and stability of Foxp3 expression (Kim and Leonard 2007; Polansky et al. 2008; Josefowitz et al. 2009). Despite these advances, the transcriptional and epigenetic mechanisms of heritable maintenance of Foxp3 expression in dividing Treg cells, including, but not limited to those, enabled by demethylation of the intronic $\mathrm{CpG}$ island, remain largely unknown. In this regard, Foxp3 protein itself appears to be necessary for heritable Foxp3 expression, but not for Foxp3 transcriptional activity in nondividing cells (Gavin et al. 2007). These observations suggest a simple feedforward mechanism of Treg lineage stability (Fig. 1).

\section{Molecular mechanisms of Treg-mediated suppression}

Despite the rapidly accumulating knowledge of Treg cell involvement in immune regulation, the understanding of molecular mechanisms of suppression is still limited. Several groups employed DNA microarray analyses to uncover molecular mechanisms facilitating suppressor function of Treg cells. As we briefly discuss below, these efforts were very productive.

Transcriptional profiling of Treg cells versus naive or activated $T$ cells revealed a substantial number of functionally important genes including cell surface molecules and secreted proteins including well-known makers of Treg cells like CD25 and CTLA-4 and new players like TNF receptor family member GITR and a neuronal guidance protein neuropilin-1 (Nrp-1) (Gavin et al. 2002; McHugh et al. 2002; Bruder et al. 2004; Herman et al. 2004; Fontenot et al. 2005b). Although an indispensable role of IL2R signaling in Treg homeostasis has been well established (Fontenot et al. 2005b; Malek 2008), a proposed role for GITR as a negative regulator of Tregmediated suppression has been controversial (McHugh et al. 2002; Shimizu et al. 2002; Ronchetti et al. 2004; Stephens et al. 2004). In addition to elevated expression on Treg cells, GITR is up-regulated on activated effector 
$\mathrm{T}$ cells, where along with other TNFR family members OX40, 41BB and TNFRII, it serves as a potent costimulatory and survival molecule. It seems more likely that engagement of GITR on the surface of effector T cells enhances their responses, effectively releasing these cells from the Treg-mediated suppression (Ronchetti et al. 2004; Stephens et al. 2004). Consistent with these results, GITR deficiency does not result in noticeable aberrations in immune homeostasis or tolerance (Ronchetti et al. 2002), yet GITR may serve as a promising target for cancer immunotherapy.

In contrast to GITR, CTLA-4, which like GITR is upregulated on effector $\mathrm{T}$ cells and is constitutively expressed at a high level on Treg cells, is indispensable for immune homeostasis. At 3 wk of age, CTLA-4-deficient mice succumb to a highly aggressive immune lesions manifested in splenomegaly, lymphadenopathy, myocarditis, and pancreatitis (Tivol et al. 1995). Although CTLA4 plays an important cell-intrinsic role in limiting responses of activated $\mathrm{T}$ cells, a surprising observation that the presence of CTLA-4-sufficient T cells prevents excessive activation of CTLA-4-deficient $T$ cells pointed to an important function of CTLA-4 in Treg-mediated suppression (Bachmann et al. 1999). Building on earlier reports using cell transfer and antibody blockade (Read et al. 2000, 2006; Takahashi et al. 2000), a role of CTLA-4 in Treg cells has been reassessed recently in genetic studies, where the mice with a selective loss of CTLA-4 in Treg cells were analyzed (Wing et al. 2008; Friedline et al. 2009; Y Rubstov and A Rudensky, in prep.). In these studies, selective CTLA-4 deficiency resulted in greatly increased numbers and activation of Treg cells under inflammatory conditions, yet the suppressive activity of CTLA-4-deficient Treg cells was impaired. It was suggested that in BALB/c mice, known for their susceptibility to a variety of immune-mediated disorders, the reduced suppression capacity of CTLA-4-deficient Treg cells is due to their inability of down-regulating CD80 and CD86 expression on and expansion of DCs (Wing et al. 2008). These results were consistent with a pronounced expansion and activation of DCs observed very early upon acute Treg cell ablation (Kim et al. 2007). Unexpectedly, however, Treg-specific ablation of CTLA-4 on a less autoimmune-prone genetic background of C57Bl6 mice does not cause an increase in DC numbers or CD80/CD86 expression, yet Treg cell suppressor capacity was impaired albeit only partially (Y Rubstov and A Rudensky, in prep.). Thus, CTLA-4 likely has additional, yet to be discovered functions in facilitating Treg suppression.

These results also raise a possibility that in addition to CTLA-4, other surface molecules highly expressed by Treg cells might contribute to suppression of DC activation, making this aspect of CTLA-4 function in Treg cells redundant in a genetic background less susceptible to autoimmunity. The latter possibility is supported by a recent discovery of a novel Ig family member TIGIT expressed, like CTLA-4, at a very high level on Treg cells and on activated conventional $\mathrm{T}$ cells. It appears that upon Treg interactions with DCs TIGIT induces production of immunosuppressive cytokines IL-10 and TGFß by DCs (Yu et al. 2009). Long-lasting Treg cell interactions with DCs were convincingly documented by recent studies employing intravital microscopy (Tadokoro et al. 2006; Tang et al. 2006). These interactions are facilitated by Nrp-1 highly expressed by the majority of Treg cells, and Nrp-1 blockade interferes with suppression mediated by Treg cells (Sarris et al. 2008).

In addition to functionally important transmembrane molecules, a number of secreted proteins identified in gene expression analyses, including granzyme B, IL-9, IL10, and IL-35, have also been implicated in Treg cellmediated suppression function. Finally, elaboration of adenosine facilitated by ectoenzymes CD73 and CD39, highly expressed on Treg cells, and extrusion of cAMP likely contribute to Treg-mediated suppression (Kobie et al. 2006; Bopp et al. 2007; Borsellino et al. 2007; Deaglio et al. 2007).

It is important to note that none of the aforementioned mechanisms of suppression can singly account for Tregmediated control of immunity. Most likely, distinct suppressor mechanisms prominently feature in particular tissue and inflammatory settings. In this regard, studies using experimental skin transplantation models suggested that Treg-derived granzyme B and IL-9 contribute to long-lived transplanted graft survival ( $\mathrm{Lu}$ et al. 2006; Gondek et al. 2008), whereas IL-10 and IL-35 secreted by Treg cells likely limit inflammation in the colon (Collison et al. 2007; Rubtsov et al. 2008).

\section{A role of Foxp3 in Treg transcriptional and functional programs}

The aforementioned central role of Foxp3 in defining Treg cell lineage raised a question as to what degree that Tregspecific genomic program is directly controlled by Foxp3. Based on comparison of gene expression profiles in Foxp3 ${ }^{+}$ $\mathrm{T}$ cells generated under different conditions (Sugimoto et al. 2006; Hill et al. 2007), it was suggested that the distinct Foxp3-independent features of Treg transcriptional program precede and are established in parallel with the Foxp3-dependent transcriptional program. A direct investigation of Foxp3 contribution to transcriptional and functional features of Treg cells was made possible through the analysis of mice harboring a Foxp3 reporter-null allele (Foxp $3^{G F P K O}$ ) generated upon insertion of a GFP coding sequence into the Foxp3 locus with a concomitant ablation of the Foxp3 protein expression (Gavin et al. 2007). Cells expressing FOxp3 ${ }^{\text {GFPKO }}$ can be arguably considered an equivalent of Treg precursor cells. These cells exhibit some of phenotypic and molecular characteristics of Foxp $3^{+}$Treg cells, including an inability to proliferate and produce IL-2 in response to TCR stimulation, expression of low amounts of IL7R $\alpha$ chain, and elevated CD25, CTLA-4, and GITR, albeit at significantly lower levels in comparison of Treg cells. However, unlike Treg cells, $\mathrm{GFP}^{+} F o x p 3^{\text {GFPKO }} \mathrm{T}$ cells produce immune response promoting Th2 and Th17 cytokines IL-4 and IL-17, and the block in their autonomous proliferative activity is less severe as their in vitro proliferation can be 
readily restored by limited TCR/CD28 costimulation. The Foxp3-mediated repression of IL-17 production, a characteristic feature of Th17 cells, is likely due to a modulation of transcriptional activity of orphan nuclear receptors ROR $\gamma$ and ROR $\alpha$ through direct interaction of Foxp3 (L Zhou et al. 2008). ROR $\gamma$ serves a role of a key Th17 lineage specifying factor (Ivanov et al. 2006). In addition, $\mathrm{GFP}^{+} F O x p 3^{G F P K O}$ T-cell population were quiescent, whereas Foxp $3^{+}$Treg cell subset exhibits impressive proliferative activity in vivo in the absence of inflammation. Most importantly, $\mathrm{GFP}^{+} F$ Foxp $3^{\mathrm{GFPKO}} \mathrm{T}$ cells were completely devoid of suppressor activity (Gavin et al. 2007). Similar results were obtained by Chatila and colleagues (Lin et al. 2007) using analogous knock-in strategy, although notable differences in the phenotype of $\mathrm{T}$ cells expressing dysfunctional Foxp3 allele were observed in the latter study, most likely due to the presence of Foxp3 protein lacking DNA-binding domain, yet capable of protein-protein interactions (Lin et al. 2007), in contrast to a complete Foxp3 ablation in the former study (Gavin et al. 2007). Together these studies showed that Foxp3 is absolutely required for suppressor function, proliferative potential, and metabolic fitness of Treg cells. In addition, Foxp3 prevents differentiation of Treg precursor cells into effector T-cell lineages. Characteristically, Foxp3 amplifies and stabilizes expression of a number of genes transiently up-regulated in activated nonregulatory $\mathrm{T}$ cells. At the same time, Foxp3 enforces repression of immune response promoting genes normally induced in naïve and effector T cells upon TCR stimulation. Thus, Foxp3 controls Treg cell differentiation by potentiating or consolidating the beneficial features and at the same time correcting the disadvantageous features of precursor cells.

The analyses of Foxp3-dependent transcriptional program invited a question as to how many genes are directly regulated by Foxp3. Recently, a systemic examination of Foxp3 target genes was undertaken using a combination of chromatin immunoprecipitation (ChIP) with mouse genome tiling array or promoter array analyses (Marson et al. 2007; Zheng et al. 2007). A cross-comparison of the data sets of Foxp3-bound genes and genes differentially expressed in Foxp $3^{+}$Treg cells versus GFP ${ }^{+}$Foxp $3^{\text {GFPKO }} \mathrm{T}$ cells revealed that $\sim 10 \%$ of Foxp3-dependent genes are directly regulated by Foxp3 (Zheng et al. 2007). However, the direct Foxp3 target genes include a number of sequence-specific transcription factors and miRNAs, playing important roles in Treg biology and contributing to differential mRNA and protein expression in Treg cells (Fig. 2; Zheng et al. 2007). The analysis of Foxp3-binding genes also showed that in contrast to early notion that Foxp3 acts as a transcriptional repressor (Schubert et al. 2001; Bettelli et al. 2005; Grant et al. 2006; Lopes et al. 2006), more Foxp3-bound genes are up-regulated, than repressed, in Treg cells (Zheng et al. 2007). Thus, Foxp3 acts as both transcriptional activator and repressor. Furthermore, Foxp3 binding correlates with marked enrichment in permissive (H3K4me3) and inhibitory (H3K27me3) histone modifications associated with its binding sites in activated and repressed genes, respec-

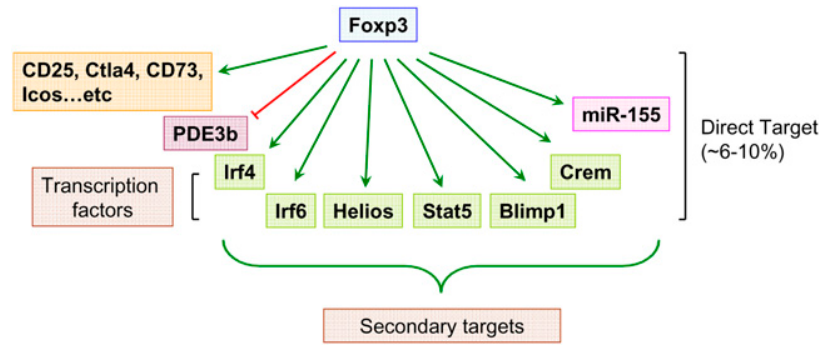

Figure 2. Foxp3-dependent transcriptional program. Foxp3 acts as both transcriptional activator and repressor. Whereas more genes are up-regulated by Foxp3 (green) in Treg cells, a number of genes are down-regulated (red) in a Foxp3-dependent manner. Genome-wide analysis of Foxp3-binding sites revealed that a relatively small fraction $(\sim 6 \%-10 \%)$ of Foxp3-dependent genes are direct targets of Foxp3. In addition, Foxp3 controls Treg cell transcriptional program indirectly through modulating expression of a set of genes encoding transcription factors and miRNA.

tively (Zheng et al. 2007). These results suggest that Foxp3 imparts epigenetic marks on its target genes and, thereby, establishes a heritable transcriptional program during Treg differentiation. However, ablation of a conditional Foxp3 allele in mature Treg cells over time resulted in a loss of characteristic gene expression, suppressor function, and the acquisition of effector T-cell function (Williams and Rudensky 2007). These results indicate that heritable maintenance of developmentally established Treg transcriptional and functional program requires continuous expression of Foxp3. Subsequent study demonstrated a similar requirement for Pax5 for the maintenance of the B-cell lineage identity (Cobaleda et al. 2007). These observations suggest that this is likely a common feature of late cellular differentiation.

\section{Treg cell-mediated suppression of distinct classes of the immune response}

Foxp3-dependent suppressor program implemented by Treg cells keeps in check Th1, Th2, and Th17 types of effector immune responses to "self" antigens and pathogens. Until very recently it was not clear whether Treg cells implement a universal hard-wired program to limit different types of immunity or modular programs of suppression tailored to inhibit a particular class of the immune response. Experimental support for the latter notion comes from a recent analysis of a role for transcription factor IRF4 in regulatory $\mathrm{T}$ cells. In naïve nonregulatory CD4 $\mathrm{T}$ cells, IRF4 is expressed at a very low level, but it is up-regulated upon their activation and its expression is required for Th2 differentiation (Lohoff et al. 2002; Rengarajan et al. 2002). Unlike conventional $\mathrm{T}$ cells, Treg cells constitutively express high level of IRF4, which serves as a direct target of Foxp3 (Zheng et al. 2007). Ablation of a conditional IRF4 allele in Treg cells led to a selective dysregulation of unprovoked pathogenic Th2 responses; i.e., increased production of Th2 cytokines, IL-4-dependent Ig isotype production, and 
pronounced plasma cell infiltration (Zheng et al. 2009). Thus, IRF4, a transcriptional factor required for differentiation of Th2 effector cells, is expressed in Treg cells in a Foxp3-dependent manner and endows Treg cells with the ability to suppress Th2 responses. Furthermore, IRF4 forms complexes with Foxp3 and in a cooperative manner regulates at least some of the genes in Treg cells; e.g., Icos, encoding an essential costimulatory molecule. These findings suggest Treg cells might hijack certain components of cell transcriptional machinery guiding differentiation of a particular effector T-cell type to efficiently control the corresponding type of the immune response.

\section{Foxp3 and its interaction partners}

The aforementioned interactions of IRF4 and ROR $\gamma$ with Foxp3 highlight the importance of understanding the composition of Foxp3 transcriptional complexes and different modalities afforded by Foxp3-interacting partners. Recent mass-spectrometric analysis of Foxp3 protein complexes isolated by immunoprecipitation revealed numerous regulators of gene expression, including factors involved in chromatin remodeling (BRG1, Ku70/Ku80, and MBD3), acetyltransferase TIP60 and histone deacetylase HDAC7, and sequence-specific transcription factors (Li and Greene 2007). It was also proposed that the recruitment of TIP60 into Foxp3 transcriptional complexes results in Foxp3 acetylation, whereas HDAC7 deacetylates Foxp3, and that the ensuing changes in the Foxp3 acetylation state modulate Foxp3 activity in a manner analogous to c-myc (Patel et al. 2004; Li et al. 2007). Among sequence-specific transcription factors serving as Foxp3 interaction partners, NFAT and Runt domain transcription factor Runx1 were proposed to be indispensable for establishing Treg transcriptional and functional programs (Wu et al. 2006; Ono et al. 2007). The molecular details of NFAT-Foxp3 interactions were deduced from crystallographic analysis of DNA-bound NFAT and the forkhead domain of Foxp2, a close relative of Foxp3 (Wu et al. 2006). DNA template-dependent interactions of Foxp3 with NFAT are thought to prevent formation of NFAT-AP-1 complexes, required for the expression of immune response-promoting genes in effector $\mathrm{T}$ cells, thereby ensuring their repression in Treg cells. NFAT:Foxp3 cooperation is able to drive the genomic program required for Treg cell differentiation and function (Wu et al. 2006). In addition, it has been suggested that Foxp3 might inhibit AP-1 function through direct association with the activated AP-1 protein (Lee et al. 2008). Site-directed mutagenesis of predicted NFAT interactions sites in the DNA-binding domain of the Foxp3 protein resulted in a loss of its ability to impose Treg gene signature and suppressor function (Wu et al. 2006). A similar loss of function was observed upon introduction of mutations disrupting Foxp3 interactions with Runx1, initially identified in a yeast two-hybrid screen (Ono et al. 2007). As a note of caution, a considerable caveat to the site-mutagenesis approach is that introduced mutations might lead to a loss of additional interacting partners besides those under study. Considering the complexity of the Foxp3 "interactome," further biochemical, genetic, and functional studies of components of Foxp3 transcriptional complexes are warranted.

\section{Role of miRNA in Foxp3 $3^{+}$Treg cells}

MicroRNA (miRNA) are small untranslated RNA species, which have been implicated in the regulation of gene expression essential for organ development, cellular differentiation, homeostasis, and functioning through target mRNA degradation or translational interference (Bartel 2004). Although miRNA-mediated gene regulation is critical during B-cell differentiation (O'Carroll et al. 2007; Koralov et al. 2008), depletion of miRNA in developing thymocytes does not result in a gross perturbation of T-cell differentiation (Cobb et al. 2005; Muljo et al. 2005). However, ablation of either Dicer or Drosha, two RNase III enzymes critical for the generation of mature miRNAs, at a stage of the DP thymocyte differentiation results in reduced numbers of Foxp $3^{+}$thymocytes and peripheral Treg cells and immune-mediated lesions developing at 6 mo of age (Cobb et al. 2006; Chong et al. 2008). Likewise, a reduction in the efficiency of Foxp3 induction is also found upon stimulation of naïve Dicer-deficient $T$ cells in the presence of TGF- $\beta$ (Cobb et al. 2006). Despite a role of miRNA in the generation of Foxp $3^{+}$Treg cells both in the thymus and in the periphery, it seems unlikely miRNAs are involved in the regulation of Foxp3 amounts. Three studies found no evidence of reduced Foxp3 amounts in Treg cells in the mice with a T-cell-specific or Treg-specific Dicer or Drosha deletion (Cobb et al. 2006; Chong et al.

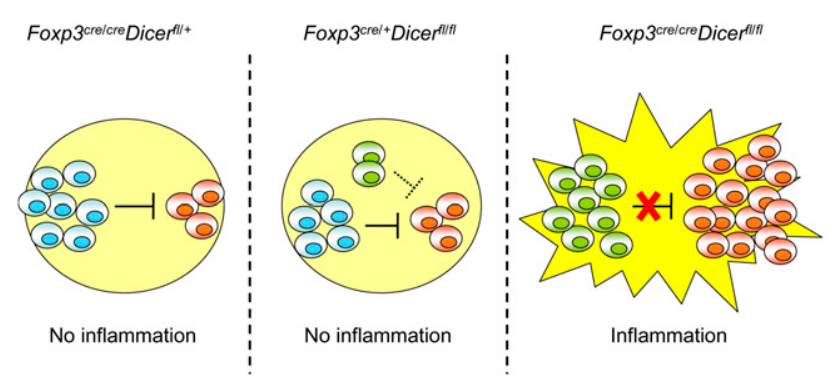

Figure 3. miRNA-dependent gene regulation preserves Treg suppressor function in inflammatory settings. miRNA depletion due to ablation of Dicer in Treg cells (green) results in impaired homeostasis and attenuated suppressor function in a healthy heterozygous Dicer ${ }^{f l / f 1}$ Foxp $3^{\text {crel+ }}$ female mice cohabited by Dicer-deficient (green) Dicer-sufficient Treg cells (blue). (Middle panel) Nevertheless, Dicer-deficient Treg cells (green) are still able to suppress self-reactive effector $\mathrm{T}$ cells (red), albeit less efficiently than their wild-type counterparts. (Left panel) Consequently, the mice remain healthy and show no sign of inflammation, similar to their wild-type littermates (Dicer ${ }^{f l /+}$ Foxp $3^{\text {cre/cre }}$ ). (Right panel) In Dicer ${ }^{\text {fl/fl }}$ Foxp $3^{\text {cre }}$ mice, lack of Dicer-sufficient Treg cells results in an inflammation and a complete loss of suppressor capacity of Dicer-deficient Treg cells. This failure of suppressor function in face of inflammation ultimately leads to fatal immune lesions indistinguishable from that in Treg-deficient mice. 
2008; Liston et al. 2008). However, upon deletion of a conditional Dicer allele mediated by a Foxp3 BAC transgene encoding YFP-Cre, a significant proportion of Dicerdeficient Treg cells became Foxp3 negative, implicating miRNA in Treg lineage stabilization (X Zhou et al. 2008). Finally, miRNA pathway also promotes survival and proliferative potential of Treg cells similar to its role in T-and B-cell lineages (Liston et al. 2008).

In addition to its role in Treg development and homeostasis, miRNA-dependent regulation of gene expression is also critical to controlling Treg cell function. Depletion of miRNA within the Treg cell lineage resulted in a fatal autoimmunity indistinguishable from that in Treg-deficient mice (Chong et al. 2008; Liston et al. 2008; X Zhou et al. 2008). Importantly, the suppressor capacity of Dicer-deficient Treg cells was maintained, albeit at a markedly reduced level, under noninflammatory conditions. However, in inflammatory settings, these cells entirely lost the suppressive capacity despite a marked increase in their numbers and activation (Liston et al. 2008). These observations implicate miRNA as key guardians of a stable Treg suppressor program under inflammatory conditions (Fig. 3).

Treg-specific Dicer and Drosha ablation studies raised a question as to the identity of specific miRNAs regulating distinct aspects of Treg biology. Differential miRNAs expression in Foxp $3^{+}$Treg cells was first demonstrated by Cobb et al. (2006). Furthermore, many of Treg-specific miRNAs are expressed in Treg cells in a Foxp3-dependent manner. Among Foxp3-dependent miRNAs, miR-155 has been shown to be directly regulated by Foxp3 (Marson et al. 2007; Zheng et al. 2007; Lu et al. 2009). Although dispensable for Treg differentiation and suppressor function, Foxp3-driven miR-155 up-regulation is critical for heightened responsiveness of Treg cells to their key survival and growth factor, IL-2. At a mechanistic level, miR-155-mediated control of Treg cell homeostasis is mediated through targeting SOCS1, a negative regulator of IL-2R signaling. Thus, constitutively high expression of

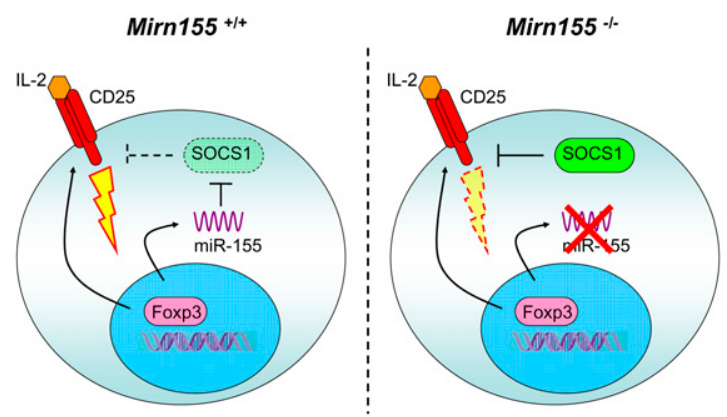

Figure 4. miR-155-dependent regulation of Treg cell homeostasis. In addition to CD25, Foxp3 induces high level of miR-155 expression to ensure increased IL-2 responsiveness through miR155-mediated down-regulation of the SOCS1 protein (left panel). In the absence of miR-155 (right panel), increased amounts of the SOCS1 protein attenuate IL-2R signaling, leading to diminished STAT5 phosphorylation and diminished competitive fitness.
miR-155 driven by Foxp3 ensures efficient STAT5 phosphorylation in the presence of limiting amounts of IL-2 and, thus, fitness of Treg cell subset in a competitive environment (Fig. 4; Lu et al. 2009). This finding not only provides the first example of a single miRNA controlling Treg homeostasis but also demonstrates that different miRNAs affect distinct facets of Treg biology.

\section{Concluding remarks}

The discovery of Treg cells and of their key controller, Foxp3, has revitalized the field of immunological tolerance. The regulation of Foxp3 expression, identification of its interaction partners and downstream gene targets provide essential mechanistic insights into highly complex and intricate regulation of immune homeostasis mediated by Treg cells. Recent advances have made Treg biology a fascinating research field amenable to mechanistic dissection. From a general biological perspective, Foxp3 and Treg cells provide a powerful model to dissect the molecular orchestration of cellular differentiation, function, and homeostasis. From an immunological point of view, in-depth exploration of Treg biology is fundamental to understanding the origin and mechanisms of dominant tolerance, a vital and unique means of negative regulation in the immune system. On a practical level, Treg manipulation offers promise for developing novel therapeutic approaches in cancer, autoimmune and infectious diseases.

\section{Acknowledgments}

We thank Meinrad Busslinger for sharing with us unpublished observations. This work was supported by NIH (A.Y.R.). L.L.F. is a Leukemia and Lymphoma Society Fellow. A.Y.R. is a Howard Hughes Medical Institute investigator.

\section{References}

Allan SE, Passerini L, Bacchetta R, Crellin N, Dai M, Orban PC, Ziegler SF, Roncarolo MG, Levings MK. 2005. The role of 2 FOXP3 isoforms in the generation of human CD4+ Tregs. J Clin Invest 115: 3276-3284.

Apostolou I, Sarukhan A, Klein L, von Boehmer H. 2002. Origin of regulatory $\mathrm{T}$ cells with known specificity for antigen. Nat Immunol 3: 756-763.

Asano M, Toda M, Sakaguchi N, Sakaguchi S. 1996. Autoimmune disease as a consequence of developmental abnormality of a T cell subpopulation. J Exp Med 184: 387-396.

Bachmann MF, Kohler G, Ecabert B, Mak TW, Kopf M. 1999. Cutting edge: Lymphoproliferative disease in the absence of CTLA-4 is not T cell autonomous. I Immunol 163: 11281131.

Baron U, Floess S, Wieczorek G, Baumann K, Grutzkau A, Dong J, Thiel A, Boeld TJ, Hoffmann P, Edinger M, et al. 2007. DNA demethylation in the human FOXP3 locus discriminates regulatory $\mathrm{T}$ cells from activated $\mathrm{FOXP}^{+}$conventional T cells. Eur J Immunol 37: 2378-2389.

Bartel DP. 2004. MicroRNAs: Genomics, biogenesis, mechanism, and function. Cell 116: 281-297.

Bayer AL, Yu A, Adeegbe D, Malek TR. 2005. Essential role for interleukin- 2 for $\mathrm{CD} 4{ }^{+} \mathrm{CD} 25^{+} \mathrm{T}$ regulatory cell development during the neonatal period. I Exp Med 201: 769-777. 
Bennett CL, Christie I, Ramsdell F, Brunkow ME, Ferguson PJ, Whitesell L, Kelly TE, Saulsbury FT, Chance PF, Ochs HD. 2001. The immune dysregulation, polyendocrinopathy, enteropathy, X-linked syndrome (IPEX) is caused by mutations of FOXP3. Nat Genet 27: 20-21.

Bettelli E, Dastrange M, Oukka M. 2005. Foxp3 interacts with nuclear factor of activated $\mathrm{T}$ cells and NF-kB to repress cytokine gene expression and effector functions of $\mathrm{T}$ helper cells. Proc Natl Acad Sci 102: 5138-5143.

Bettelli E, Carrier Y, Gao W, Korn T, Strom TB, Oukka M, Weiner HL, Kuchroo VK. 2006. Reciprocal developmental pathways for the generation of pathogenic effector TH17 and regulatory T cells. Nature 441: 235-238.

Bonomo A, Kehn PI, Payer E, Rizzo L, Cheever AW, Shevach EM. 1995. Pathogenesis of post-thymectomy autoimmunity. Role of syngeneic MLR-reactive T cells. J Immunol 154: 6602-6611.

Bopp T, Becker C, Klein M, Klein-Hessling S, Palmetshofer A, Serfling E, Heib V, Becker M, Kubach J, Schmitt S, et al. 2007. Cyclic adenosine monophosphate is a key component of regulatory T cell-mediated suppression. J Exp Med 204: 13031310.

Borsellino G, Kleinewietfeld M, Di Mitri D, Sternjak A, Diamantini A, Giometto R, Hopner S, Centonze D, Bernardi G, Dell'Acqua ML, et al. 2007. Expression of ectonucleotidase CD39 by Foxp3 ${ }^{+}$Treg cells: Hydrolysis of extracellular ATP and immune suppression. Blood 110: 1225-1232.

Bruder D, Probst-Kepper M, Westendorf AM, Geffers R, Beissert S, Loser K, von Boehmer H, Buer J, Hansen W. 2004. Neuropilin-1: A surface marker of regulatory T cells. Eur I Immunol 34: 623-630.

Burchill MA, Goetz CA, Prlic M, O'Neil JJ, Harmon IR, Bensinger SJ, Turka LA, Brennan P, Jameson SC, Farrar MA. 2003. Distinct effects of STAT5 activation on $\mathrm{CD}^{+}$and $\mathrm{CD}^{+} \mathrm{T}$ cell homeostasis: Development of $\mathrm{CD} 4^{+} \mathrm{CD} 25^{+}$ regulatory $\mathrm{T}$ cells versus $\mathrm{CD} 8^{+}$memory $\mathrm{T}$ cells. I Immunol 171: 5853-5864.

Burchill MA, Yang J, Vogtenhuber C, Blazar BR, Farrar MA. 2007. IL-2 receptor $\beta$-dependent STAT5 activation is required for the development of Foxp $3^{+}$regulatory T cells. I Immunol 178: $280-290$.

Burchill MA, Yang J, Vang KB, Moon JJ, Chu HH, Lio CW, Vegoe AL, Hsieh CS, Jenkins MK, Farrar MA. 2008. Linked T cell receptor and cytokine signaling govern the development of the regulatory $\mathrm{T}$ cell repertoire. Immunity 28: 112-121.

Chatila TA, Blaeser F, Ho N, Lederman HM, Voulgaropoulos C, Helms C, Bowcock AM. 2000. JM2, encoding a fork headrelated protein, is mutated in X-linked autoimmunityallergic disregulation syndrome. I Clin Invest 106: R75R81. doi: 10.1172/JCI11679.

Chen W, Jin W, Hardegen N, Lei KJ, Li L, Marinos N, McGrady G, Wahl SM. 2003. Conversion of peripheral CD4 ${ }^{+} \mathrm{CD} 25-$ naive $\mathrm{T}$ cells to $\mathrm{CD} 4^{+} \mathrm{CD} 25^{+}$regulatory $\mathrm{T}$ cells by TGF- $\beta$ induction of transcription factor Foxp3. J Exp Med 198: 18751886.

Chen Z, Benoist C, Mathis D. 2005. How defects in central tolerance impinge on a deficiency in regulatory T cells. Proc Natl Acad Sci 102: 14735-14740.

Chong MM, Rasmussen JP, Rudensky AY, Littman DR. 2008. The RNAseIII enzyme Drosha is critical in $\mathrm{T}$ cells for preventing lethal inflammatory disease. I Exp Med 205: 2005-2017.

Cobaleda C, Jochum W, Busslinger M. 2007. Conversion of mature B cells into $T$ cells by dedifferentiation to uncommitted progenitors. Nature 449: 473-477.

Cobb BS, Nesterova TB, Thompson E, Hertweck A, O'Connor E, Godwin J, Wilson CB, Brockdorff N, Fisher AG, Smale ST, et al. 2005. T cell lineage choice and differentiation in the absence of the RNase III enzyme Dicer. J Exp Med 201: 13671373.

Cobb BS, Hertweck A, Smith J, O'Connor E, Graf D, Cook T, Smale ST, Sakaguchi S, Livesey FJ, Fisher AG, et al. 2006. A role for Dicer in immune regulation. I Exp Med 203: 25192527.

Collison LW, Workman CJ, Kuo TT, Boyd K, Wang Y, Vignali KM, Cross R, Sehy D, Blumberg RS, Vignali DA. 2007. The inhibitory cytokine IL-35 contributes to regulatory T-cell function. Nature 450: 566-569.

Davidson TS, DiPaolo RJ, Andersson J, Shevach EM. 2007. Cutting edge: IL- 2 is essential for TGF- $\beta$-mediated induction of Foxp ${ }^{+}$T regulatory cells. I Immunol 178: 4022-4026.

Deaglio S, Dwyer KM, Gao W, Friedman D, Usheva A, Erat A, Chen JF, Enjyoji K, Linden J, Oukka M, et al. 2007. Adenosine generation catalyzed by CD39 and CD73 expressed on regulatory $\mathrm{T}$ cells mediates immune suppression. I Exp Med 204: 1257-1265.

Fehervari Z, Sakaguchi S. 2004. CD4+ Tregs and immune control. J Clin Invest 114: 1209-1217.

Floess S, Freyer J, Siewert C, Baron U, Olek S, Polansky J, Schlawe K, Chang HD, Bopp T, Schmitt E, et al. 2007. Epigenetic control of the foxp3 locus in regulatory $\mathrm{T}$ cells. PLOS Biol 5: e38. doi: 10.1371/journal.pbio.0050038.

Fontenot JD, Gavin MA, Rudensky AY. 2003. Foxp3 programs the development and function of $\mathrm{CD} 4{ }^{+} \mathrm{CD} 25^{+}$regulatory $\mathrm{T}$ cells. Nat Immunol 4: 330-336.

Fontenot JD, Dooley JL, Farr AG, Rudensky AY. 2005a. Developmental regulation of Foxp3 expression during ontogeny. J Exp Med 202: 901-906.

Fontenot JD, Rasmussen JP, Gavin MA, Rudensky AY. 2005b. A function for interleukin 2 in Foxp3-expressing regulatory $\mathrm{T}$ cells. Nat Immunol 6: 1142-1151.

Fontenot JD, Rasmussen JP, Williams LM, Dooley JL, Farr AG, Rudensky AY. 2005c. Regulatory T cell lineage specification by the forkhead transcription factor foxp3. Immunity 22: 329-341.

Friedline RH, Brown DS, Nguyen H, Kornfeld H, Lee J, Zhang Y, Appleby M, Der SD, Kang J, Chambers CA. 2009. CD4 ${ }^{+}$ regulatory $\mathrm{T}$ cells require CTLA-4 for the maintenance of systemic tolerance. I Exp Med 16: 421-434.

Furtado GC, Curotto de Lafaille MA, Kutchukhidze N, Lafaille JJ. 2002. Interleukin 2 signaling is required for $\mathrm{CD}^{+}$regulatory T cell function. J Exp Med 196: 851-857.

Gambineri E, Torgerson TR, Ochs HD. 2003. Immune dysregulation, polyendocrinopathy, enteropathy, and X-linked inheritance (IPEX), a syndrome of systemic autoimmunity caused by mutations of FOXP3, a critical regulator of T-cell homeostasis. Curr Opin Rheumatol 15: 430-435.

Gavin MA, Clarke SR, Negrou E, Gallegos A, Rudensky A. 2002. Homeostasis and anergy of $\mathrm{CD} 4^{+} \mathrm{CD} 25^{+}$suppressor T cells in vivo. Nat Immunol 3: 33-41.

Gavin MA, Torgerson TR, Houston E, DeRoos P, Ho WY, Stray-Pedersen A, Ocheltree EL, Greenberg PD, Ochs HD, Rudensky AY. 2006. Single-cell analysis of normal and FOXP3-mutant human T cells: FOXP3 expression without regulatory T cell development. Proc Natl Acad Sci 103: 6659-6664.

Gavin MA, Rasmussen JP, Fontenot JD, Vasta V, Manganiello VC, Beavo JA, Rudensky AY. 2007. Foxp3-dependent programme of regulatory T-cell differentiation. Nature 445: 771775.

Godfrey VL, Rouse BT, Wilkinson JE. 1994. Transplantation of T cell-mediated, lymphoreticular disease from the scurfy (sf) mouse. Am J Pathol 145: 281-286. 
Gondek DC, Devries V, Nowak EC, Lu LF, Bennett KA, Scott ZA, Noelle RJ. 2008. Transplantation survival is maintained by granzyme $\mathrm{B}+$ regulatory cells and adaptive regulatory $\mathrm{T}$ cells. J Immunol 181: 4752-4760.

Grant C, Oh U, Fugo K, Takenouchi N, Griffith C, Yao K, Newhook TE, Ratner L, Jacobson S. 2006. Foxp3 represses retroviral transcription by targeting both NF-кB and CREB pathways. PLOS Pathog 2: e33. doi: 10.1371/journal.ppat. 0020033.

Gupta S, Manicassamy S, Vasu C, Kumar A, Shang W, Sun Z. 2008. Differential requirement of PKC- $\theta$ in the development and function of natural regulatory T cells. Mol Immunol 46: 213-224.

Haxhinasto S, Mathis D, Benoist C. 2008. The AKT-mTOR axis regulates de novo differentiation of $\mathrm{CD} 4^{+} \mathrm{Foxp}^{+}$cells. I Exp Med 205: 565-574.

Herman AE, Freeman GJ, Mathis D, Benoist C. 2004. $\mathrm{CD} 4^{+} \mathrm{CD} 25^{+} \mathrm{T}$ regulatory cells dependent on ICOS promote regulation of effector cells in the prediabetic lesion. I Exp Med 199: 1479-1489.

Hill JA, Feuerer M, Tash K, Haxhinasto S, Perez J, Melamed R, Mathis D, Benoist C. 2007. Foxp3 transcription-factordependent and -independent regulation of the regulatory $\mathrm{T}$ cell transcriptional signature. Immunity 27: 786-800.

Hori S, Nomura T, Sakaguchi S. 2003. Control of regulatory T cell development by the transcription factor Foxp3. Science 299: 1057-1061.

Horwitz DA, Zheng SG, Wang J, Gray JD. 2008. Critical role of IL-2 and TGF- $\beta$ in generation, function and stabilization of Foxp $3^{+} \mathrm{CD}^{+}$Treg. Eur J Immunol 38: 912-915.

Hsieh CS, Zheng Y, Liang Y, Fontenot JD, Rudensky AY. 2006. An intersection between the self-reactive regulatory and nonregulatory $\mathrm{T}$ cell receptor repertoires. Nat Immunol 7: 401-410.

Ivanov II, McKenzie BS, Zhou L, Tadokoro CE, Lepelley A, Lafaille JJ, Cua DI, Littman DR. 2006. The orphan nuclear receptor ROR $y \mathrm{t}$ directs the differentiation program of proinflammatory IL- $17^{+} \mathrm{T}$ helper cells. Cell 126: 1121-1133.

Jordan MS, Boesteanu A, Reed AJ, Petrone AL, Holenbeck AE, Lerman MA, Naji A, Caton AJ. 2001. Thymic selection of $\mathrm{CD} 4{ }^{+} \mathrm{CD} 25^{+}$regulatory $\mathrm{T}$ cells induced by an agonist selfpeptide. Nat Immunol 2: 301-306.

Josefowicz SZ, Wilson CB, Rudensky AY. 2009. TCR stimulation is sufficient for induction of Foxp3 expression in the absence of DNA methyltransferase I. I Immunol (in press).

Khattri R, Cox T, Yasayko SA, Ramsdell F. 2003. An essential role for Scurfin in $\mathrm{CD} 4{ }^{+} \mathrm{CD} 25^{+} \mathrm{T}$ regulatory cells. Nat Immunol 4: 337-342.

Kim HP, Leonard WJ. 2007. CREB/ATF-dependent T cell receptor-induced FoxP3 gene expression: A role for DNA methylation. I Exp Med 204: 1543-1551.

Kim JM, Rasmussen JP, Rudensky AY. 2007. Regulatory T cells prevent catastrophic autoimmunity throughout the lifespan of mice. Nat Immunol 8: 191-197.

Kobie JJ, Shah PR, Yang L, Rebhahn JA, Fowell DJ, Mosmann TR. 2006. T regulatory and primed uncommitted CD4 T cells express CD73, which suppresses effector CD4 $\mathrm{T}$ cells by converting 5 '-adenosine monophosphate to adenosine. Immunol 177: 6780-6786.

Komatsu N, Mariotti-Ferrandiz ME, Wang Y, Malissen B, Waldmann H, Hori S. 2009. Heterogeneity of natural Foxp3 ${ }^{+}$ $T$ cells: A committed regulatory T-cell lineage and an uncommitted minor population retaining plasticity. Proc Natl Acad Sci 106: 1903-1908.

Koralov SB, Muljo SA, Galler GR, Krek A, Chakraborty T, Kanellopoulou C, Jensen K, Cobb BS, Merkenschlager M,
Rajewsky N, et al. 2008. Dicer ablation affects antibody diversity and cell survival in the B lymphocyte lineage. Cell 132: $860-874$.

Lafaille JJ, Nagashima K, Katsuki M, Tonegawa S. 1994. High incidence of spontaneous autoimmune encephalomyelitis in immunodeficient anti-myelin basic protein $\mathrm{T}$ cell receptor transgenic mice. Cell 78: 399-408.

Lahl K, Loddenkemper C, Drouin C, Freyer J, Arnason J, Eberl G, Hamann A, Wagner H, Huehn J, Sparwasser T. 2007. Selective depletion of Foxp $3^{+}$regulatory T cells induces a scurfylike disease. I Exp Med 204: 57-63.

Lee SM, Gao B, Fang D. 2008. FoxP3 maintains Treg unresponsiveness by selectively inhibiting the promoter DNA-binding activity of AP-1. Blood 111: 3599-3606.

Lenschow DJ, Walunas TL, Bluestone JA. 1996. CD28/B7 system of T cell costimulation. Annu Rev Immunol 14: 233-258.

Li B, Greene MI. 2007. FOXP3 actively represses transcription by recruiting the HAT/HDAC complex. Cell Cycle 6: 14321436.

Li B, Samanta A, Song X, Iacono KT, Bembas K, Tao R, Basu S, Riley JL, Hancock WW, Shen Y, et al. 2007. FOXP3 interactions with histone acetyltransferase and class II histone deacetylases are required for repression. Proc Natl Acad Sci 104: 4571-4576.

Lin W, Haribhai D, Relland LM, Truong N, Carlson MR, Williams CB, Chatila TA. 2007. Regulatory T cell development in the absence of functional Foxp3. Nat Immunol 8: 359-368.

Lio CW, Hsieh CS. 2008. A two-step process for thymic regulatory T cell development. Immunity 28: 100-111.

Liston A, Farr AG, Chen Z, Benoist C, Mathis D, Manley NR, Rudensky AY. 2007. Lack of Foxp3 function and expression in the thymic epithelium. J Exp Med 204: 475-480.

Liston A, Lu LF, O'Carroll D, Tarakhovsky A, Rudensky AY. 2008. Dicer-dependent microRNA pathway safeguards regulatory T cell function. J Exp Med 205: 1993-2004.

Liu Y, Zhang P, Li J, Kulkarni AB, Perruche S, Chen W. 2008. A critical function for TGF- $\beta$ signaling in the development of natural $\mathrm{CD} 4{ }^{+} \mathrm{CD} 25^{+} \mathrm{Foxp}^{+}{ }^{+}$regulatory T cells. Nat Immunol 9: $632-640$.

Lohoff M, Mittrucker HW, Prechtl S, Bischof S, Sommer F, Kock S, Ferrick DA, Duncan GS, Gessner A, Mak TW. 2002. Dysregulated $\mathrm{T}$ helper cell differentiation in the absence of interferon regulatory factor 4. Proc Natl Acad Sci 99: 1180811812.

Lopes JE, Torgerson TR, Schubert LA, Anover SD, Ocheltree EL, Ochs HD, Ziegler SF. 2006. Analysis of FOXP3 reveals multiple domains required for its function as a transcriptional repressor. I Immunol 177: 3133-3142.

Lu LF, Lind EF, Gondek DC, Bennett KA, Gleeson MW, PinoLagos K, Scott ZA, Coyle AJ, Reed JL, Van Snick J, et al. 2006. Mast cells are essential intermediaries in regulatory T-cell tolerance. Nature 442: 997-1002.

Lu LF, Thai TH, Calado DP, Chaudhry A, Kubo M, Tanaka K, Loeb GB, Lee H, Yoshimura A, Rajewsky K, et al. 2009. Foxp3-dependent microRNA155 confers competitive fitness to regulatory $\mathrm{T}$ cells by targeting SOCS1 protein. Immunity 30: $80-91$.

Malek TR. 2008. The biology of interleukin-2. Annu Rev Immunol 26: 453-479.

Malek TR, Yu A, Vincek V, Scibelli P, Kong L. 2002. CD4 regulatory $T$ cells prevent lethal autoimmunity in IL-2R $\beta$ deficient mice. Implications for the nonredundant function of IL-2. Immunity 17: 167-178.

Malek TR, Yu A, Zhu L, Matsutani T, Adeegbe D, Bayer AL. 2008. IL-2 family of cytokines in T regulatory cell development and homeostasis. J Clin Immunol 28: 635-639. 
Mantel PY, Ouaked N, Ruckert B, Karagiannidis C, Welz R, Blaser K, Schmidt-Weber CB. 2006. Molecular mechanisms underlying FOXP3 induction in human T cells. I Immunol 176: 3593-3602.

Marson A, Kretschmer K, Frampton GM, Jacobsen ES, Polansky JK, MacIsaac KD, Levine SS, Fraenkel E, von Boehmer H, Young RA. 2007. Foxp3 occupancy and regulation of key target genes during T-cell stimulation. Nature 445: 931-935.

McHugh RS, Whitters MJ, Piccirillo CA, Young DA, Shevach EM, Collins M, Byrne MC. 2002. CD4 ${ }^{+} \mathrm{CD} 25^{+}$immunoregulatory T cells: Gene expression analysis reveals a functional role for the glucocorticoid-induced TNF receptor. Immunity 16: 311-323.

Morgan ME, van Bilsen JH, Bakker AM, Heemskerk B, Schilham MW, Hartgers FC, Elferink BG, van der Zanden L, de Vries RR, Huizinga TW, et al. 2005. Expression of FOXP3 mRNA is not confined to $\mathrm{CD} 4^{+} \mathrm{CD} 25^{+} \mathrm{T}$ regulatory cells in humans. Hum Immunol 66: 13-20.

Muljo SA, Ansel KM, Kanellopoulou C, Livingston DM, Rao A, Rajewsky K. 2005. Aberrant $\mathrm{T}$ cell differentiation in the absence of Dicer. J Exp Med 202: 261-269.

Nishizuka Y, Sakakura T. 1969. Thymus and reproduction: Sexlinked dysgenesia of the gonad after neonatal thymectomy in mice. Science 166: 753-755.

O'Carroll D, Mecklenbrauker I, Das PP, Santana A, Koenig U, Enright AJ, Miska EA, Tarakhovsky A. 2007. A Slicerindependent role for Argonaute 2 in hematopoiesis and the microRNA pathway. Genes \& Dev 21: 1999-2004.

Ohki H, Martin C, Corbel C, Coltey M, Le Douarin NM. 1987. Tolerance induced by thymic epithelial grafts in birds. Science 237: 1032-1035.

Olivares-Villagomez D, Wang Y, Lafaille JJ. 1998. Regulatory $\mathrm{CD}^{+} \mathrm{T}$ cells expressing endogenous $\mathrm{T}$ cell receptor chains protect myelin basic protein-specific transgenic mice from spontaneous autoimmune encephalomyelitis. J Exp Med 188: 1883-1894.

Ono M, Yaguchi H, Ohkura N, Kitabayashi I, Nagamura Y, Nomura T, Miyachi Y, Tsukada T, Sakaguchi S. 2007. Foxp3 controls regulatory T-cell function by interacting with AML1/Runx1. Nature 446: 685-689.

Ou-Yang HF, Zhang HW, Wu CG, Zhang P, Zhang J, Li JC, Hou LH, He F, Ti XY, Song LQ, et al. 2009. Notch signaling regulates the FOXP3 promoter through RBP-J- and Hes1-dependent mechanisms. Mol Cell Biochem 320: 109114.

Patel JH, Du Y, Ard PG, Phillips C, Carella B, Chen CJ, Rakowski C, Chatterjee C, Lieberman PM, Lane WS, et al. 2004. The c-MYC oncoprotein is a substrate of the acetyltransferases hGCN5/PCAF and TIP60. Mol Cell Biol 24: 10826-10834.

Patton DT, Garden OA, Pearce WP, Clough LE, Monk CR, Leung E, Rowan WC, Sancho S, Walker LS, Vanhaesebroeck B, et al. 2006. Cutting edge: The phosphoinositide 3-kinase p110 $\delta$ is critical for the function of $\mathrm{CD} 4^{+} \mathrm{CD} 25^{+} \mathrm{Foxp} 3^{+}$regulatory $\mathrm{T}$ cells. J Immunol 177: 6598-6602.

Polansky JK, Kretschmer K, Freyer J, Floess S, Garbe A, Baron U, Olek S, Hamann A, von Boehmer H, Huehn J. 2008. DNA methylation controls Foxp3 gene expression. Eur I Immunol 38: 1654-1663.

Read S, Malmstrom V, Powrie F. 2000. Cytotoxic T lymphocyteassociated antigen 4 plays an essential role in the function of $\mathrm{CD} 25^{+} \mathrm{CD} 4^{+}$regulatory cells that control intestinal inflammation. J Exp Med 192: 295-302.

Read S, Greenwald R, Izcue A, Robinson N, Mandelbrot D, Francisco L, Sharpe AH, Powrie F. 2006. Blockade of CTLA-4 on $\mathrm{CD} 4{ }^{+} \mathrm{CD} 25^{+}$regulatory $\mathrm{T}$ cells abrogates their function in vivo. I Immunol 177: 4376-4383.

Rengarajan J, Mowen KA, McBride KD, Smith ED, Singh H, Glimcher LH. 2002. Interferon regulatory factor 4 (IRF4) interacts with NFATc2 to modulate interleukin 4 gene expression. J Exp Med 195: 1003-1012.

Ronchetti S, Nocentini G, Riccardi C, Pandolfi PP. 2002. Role of GITR in activation response of T lymphocytes. Blood 100: 350-352.

Ronchetti S, Zollo O, Bruscoli S, Agostini M, Bianchini R, Nocentini G, Ayroldi E, Riccardi C. 2004. GITR, a member of the TNF receptor superfamily, is costimulatory to mouse $\mathrm{T}$ lymphocyte subpopulations. Eur I Immunol 34: 613-622.

Rubtsov YP, Rasmussen JP, Chi EY, Fontenot J, Castell L, Ye X, Treuting P, Siewe L, Roers A, Henderson WRJ, et al. 2008. IL10 produced by regulatory $\mathrm{T}$ cells contributes to their suppressor function by limiting inflammation at environmental interfaces. Immunity 28: 546-558.

Sakaguchi S. 2004. Naturally arising $\mathrm{CD}^{+}$regulatory T cells for immunologic self-tolerance and negative control of immune responses. Annu Rev Immunol 22: 531-562.

Sakaguchi S, Takahashi T, Nishizuka Y. 1982. Study on cellular events in postthymectomy autoimmune oophoritis in mice. I. Requirement of Lyt-1 effector cells for oocytes damage after adoptive transfer. J Exp Med 156: 1565-1576.

Sakaguchi S, Sakaguchi N, Asano M, Itoh M, Toda M. 1995. Immunologic self-tolerance maintained by activated $\mathrm{T}$ cells expressing IL-2 receptor $\alpha$-chains (CD25). Breakdown of a single mechanism of self-tolerance causes various autoimmune diseases. I Immunol 155: 1151-1164.

Salomon B, Lenschow DJ, Rhee L, Ashourian N, Singh B, Sharpe A, Bluestone JA. 2000. B7/CD28 costimulation is essential for the homeostasis of the $\mathrm{CD} 4{ }^{+} \mathrm{CD} 25^{+}$immunoregulatory $\mathrm{T}$ cells that control autoimmune diabetes. Immunity 12: 431440.

Samon JB, Champhekar A, Minter LM, Telfer JC, Miele L, Fauq A, Das P, Golde TE, Osborne BA. 2008. Notch1 and TGF 1 cooperatively regulate Foxp3 expression and the maintenance of peripheral regulatory T cells. Blood 112: 1813-1821.

Sarris M, Andersen KG, Randow F, Mayr L, Betz AG. 2008. Neuropilin-1 expression on regulatory $\mathrm{T}$ cells enhances their interactions with dendritic cells during antigen recognition. Immunity 28: 402-413.

Sauer S, Bruno L, Hertweck A, Finlay D, Leleu M, Spivakov M, Knight ZA, Cobb BS, Cantrell D, O'Connor E, et al. 2008. T cell receptor signaling controls Foxp3 expression via PI3K, Akt, and mTOR. Proc Natl Acad Sci 105: 7797-7802.

Schmidt-Supprian M, Tian J, Grant EP, Pasparakis M, Maehr R, Ovaa H, Ploegh HL, Coyle AJ, Rajewsky K. 2004. Differential dependence of $\mathrm{CD}^{+} \mathrm{CD} 25^{+}$regulatory and natural killer-like $\mathrm{T}$ cells on signals leading to NF-кB activation. Proc Natl Acad Sci 101: 4566-4571.

Schubert LA, Jeffery E, Zhang Y, Ramsdell F, Ziegler SF. 2001. Scurfin (FOXP3) acts as a repressor of transcription and regulates T cell activation. J Biol Chem 276: 37672-37679.

Shevach EM. 2000. Regulatory T cells in autoimmmunity. Annu Rev Immunol 18: 423-449.

Shimizu J, Yamazaki S, Takahashi T, Ishida Y, Sakaguchi S. 2002. Stimulation of $\mathrm{CD} 25^{+} \mathrm{CD} 4^{+}$regulatory $\mathrm{T}$ cells through GITR breaks immunological self-tolerance. Nat Immunol 3: 135-142.

Starr TK, Jameson SC, Hogquist KA. 2003. Positive and negative selection of T cells. Annu Rev Immunol 21: 139-176.

Stephens GL, McHugh RS, Whitters MJ, Young DA, Luxenberg D, Carreno BM, Collins M, Shevach EM. 2004. Engagement 
of glucocorticoid-induced TNFR family-related receptor on effector $\mathrm{T}$ cells by its ligand mediates resistance to suppression by $\mathrm{CD} 4{ }^{+} \mathrm{CD} 25^{+} \mathrm{T}$ cells. I Immunol 173: 5008-5020.

Sugimoto N, Oida T, Hirota $K$, Nakamura $K$, Nomura $T$, Uchiyama T, Sakaguchi S. 2006. Foxp3-dependent and -independent molecules specific for $\mathrm{CD} 25^{+} \mathrm{CD} 4^{+}$natural regulatory $\mathrm{T}$ cells revealed by DNA microarray analysis. Int Immunol 18: 1197-1209.

Tadokoro CE, Shakhar G, Shen S, Ding Y, Lino AC, Maraver A, Lafaille JJ, Dustin ML. 2006. Regulatory T cells inhibit stable contacts between $\mathrm{CD}^{+} \mathrm{T}$ cells and dendritic cells in vivo. $J$ Exp Med 203: 505-511.

Tai X, Cowan M, Feigenbaum L, Singer A. 2005. CD28 costimulation of developing thymocytes induces Foxp3 expression and regulatory $\mathrm{T}$ cell differentiation independently of interleukin 2. Nat Immunol 6: 152-162.

Takahashi T, Tagami T, Yamazaki S, Uede T, Shimizu J, Sakaguchi N, Mak TW, Sakaguchi S. 2000. Immunologic self-tolerance maintained by $\mathrm{CD} 25^{+} \mathrm{CD} 4^{+}$regulatory $\mathrm{T}$ cells constitutively expressing cytotoxic $\mathrm{T}$ lymphocyte-associated antigen 4. J Exp Med 192: 303-310.

Tang Q, Adams JY, Tooley AJ, Bi M, Fife BT, Serra P, Santamaria P, Locksley RM, Krummel MF, Bluestone JA. 2006. Visualizing regulatory $\mathrm{T}$ cell control of autoimmune responses in nonobese diabetic mice. Nat Immunol 7: 83-92.

Tivol EA, Borriello F, Schweitzer AN, Lynch WP, Bluestone JA, Sharpe AH. 1995. Loss of CTLA-4 leads to massive lymphoproliferation and fatal multiorgan tissue destruction, revealing a critical negative regulatory role of CTLA-4. Immunity 3: $541-547$.

Tone Y, Furuuchi K, Kojima Y, Tykocinski ML, Greene MI, Tone M. 2008. Smad3 and NFAT cooperate to induce Foxp3 expression through its enhancer. Nat Immunol 9: 194-202.

Trombetta ES, Mellman I. 2005. Cell biology of antigen processing in vitro and in vivo. Annu Rev Immunol 23: 975-1028.

Vang KB, Yang J, Mahmud SA, Burchill MA, Vegoe AL, Farrar MA. 2008. IL-2, -7, and -15, but not thymic stromal lymphopoeitin, redundantly govern $\mathrm{CD} 4^{+} \mathrm{Foxp}^{+}$regulatory $\mathrm{T}$ cell development. I Immunol 181: 3285-3290.

Walker MR, Kasprowicz DJ, Gersuk VH, Benard A, Van Landeghen M, Buckner JH, Ziegler SF. 2003. Induction of FoxP3 and acquisition of $\mathrm{T}$ regulatory activity by stimulated human CD4 ${ }^{+} \mathrm{CD} 25^{-} \mathrm{T}$ cells. J Clin Invest 112: 1437-1443.

Wan YY, Flavell RA. 2005. Identifying Foxp3-expressing suppressor T cells with a bicistronic reporter. Proc Natl Acad Sci 102: 5126-5131.

Wan YY, Flavell RA. 2007. Regulatory T-cell functions are subverted and converted owing to attenuated Foxp3 expression. Nature 445: 766-770.

Wang J, Ioan-Facsinay A, van der Voort EI, Huizinga TW, Toes RE. 2007. Transient expression of FOXP3 in human activated nonregulatory CD4 ${ }^{+}$T cells. Eur I Immunol 37: 129-138.

Wildin RS, Ramsdell F, Peake J, Faravelli F, Casanova JL, Buist N, Levy-Lahad E, Mazzella M, Goulet O, Perroni L, et al. 2001. X-linked neonatal diabetes mellitus, enteropathy and endocrinopathy syndrome is the human equivalent of mouse scurfy. Nat Genet 27: 18-20.

Williams LM, Rudensky AY. 2007. Maintenance of the Foxp3dependent developmental program in mature regulatory $\mathrm{T}$ cells requires continued expression of Foxp3. Nat Immunol 8: $277-284$.

Wing K, Onishi Y, Prieto-Martin P, Yamaguchi T, Miyara M, Fehervari Z, Nomura T, Sakaguchi S. 2008. CTLA-4 control over Foxp3 ${ }^{+}$regulatory T cell function. Science 322: 271-275.

Wu Y, Borde M, Heissmeyer V, Feuerer M, Lapan AD, Stroud JC, Bates DL, Guo L, Han A, Ziegler SF, et al. 2006. FOXP3 controls regulatory $\mathrm{T}$ cell function through cooperation with NFAT. Cell 126: 375-387.

Yao Z, Kanno Y, Kerenyi M, Stephens G, Durant L, Watford WT, Laurence A, Robinson GW, Shevach EM, Moriggl R, et al. 2007. Nonredundant roles for Stat $5 \mathrm{a} / \mathrm{b}$ in directly regulating Foxp3. Blood 109: 4368-4375.

Yu X, Harden K, Gonzalez LC, Francesco M, Chiang E, Irving B, Tom I, Ivelja S, Refino CJ, Clark H, et al. 2009. The surface protein TIGIT suppresses $\mathrm{T}$ cell activation by promoting the generation of mature immunoregulatory dendritic cells. Nat Immunol 10: 48-57.

Zheng SG, Wang JH, Gray JD, Soucier H, Horwitz DA. 2004. Natural and induced $\mathrm{CD} 4^{+} \mathrm{CD} 25^{+}$cells educate $\mathrm{CD} 4^{+} \mathrm{CD} 25^{-}$ cells to develop suppressive activity: The role of IL-2, TGF- $\beta$, and IL-10. I Immunol 172: 5213-5221.

Zheng Y, Josefowicz SZ, Kas A, Chu TT, Gavin MA, Rudensky AY. 2007. Genome-wide analysis of Foxp3 target genes in developing and mature regulatory T cells. Nature 445: 936940.

Zheng Y, Chaudhry A, Kas A, Deroos P, Kim JM, Chu TT, Corcoran L, Treuting P, Klein U, Rudensky AY. 2009. Regulatory T-cell suppressor program co-opts transcription factor IRF4 to control T(H)2 responses. Nature 458: 351-356.

Zhou L, Lopes JE, Chong MM, Ivanov II, Min R, Victora GD, Shen Y, Du J, Rubtsov YP, Rudensky AY, et al. 2008. TGF- $\beta$ induced Foxp3 inhibits $\mathrm{T}(\mathrm{H}) 17$ cell differentiation by antagonizing ROR $\gamma$ t function. Nature 453: 236-240.

Zhou X, Jeker LT, Fife BT, Zhu S, Anderson MS, McManus MT, Bluestone JA. 2008. Selective miRNA disruption in T reg cells leads to uncontrolled autoimmunity. I Exp Med 205: 1983-1991.

Ziegler SF. 2006. FOXP3: Of mice and men. Annu Rev Immunol 24: 209-226.

Zorn E, Nelson EA, Mohseni M, Porcheray F, Kim H, Litsa D, Bellucci R, Raderschall E, Canning C, Soiffer RJ, et al. 2006. IL-2 regulates FOXP3 expression in human $\mathrm{CD} 4{ }^{+} \mathrm{CD} 25^{+}$ regulatory $\mathrm{T}$ cells through a STAT-dependent mechanism and induces the expansion of these cells in vivo. Blood 108: 1571-1579.

Zuo T, Liu R, Zhang H, Chang X, Liu Y, Wang L, Zheng P. 2007a. FOXP3 is a novel transcriptional repressor for the breast cancer oncogene SKP2. I Clin Invest 117: 3765-3773.

Zuo T, Wang L, Morrison C, Chang X, Zhang H, Li W, Liu Y, Wang Y, Liu X, Chan MW, et al. 2007b. FOXP3 is an X-linked breast cancer suppressor gene and an important repressor of the HER-2/ErbB2 oncogene. Cell 129: 1275-1286. 


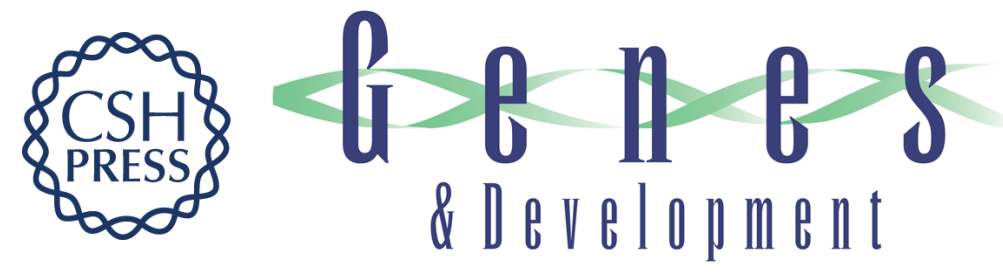

\section{Molecular orchestration of differentiation and function of regulatory $\mathrm{T}$ cells}

Li-Fan Lu and Alexander Rudensky

Genes Dev. 2009, 23:

Access the most recent version at doi:10.1101/gad.1791009

References This article cites 136 articles, 61 of which can be accessed free at: http://genesdev.cshlp.org/content/23/11/1270.full.html\#ref-list-1

License

Email Alerting Receive free email alerts when new articles cite this article - sign up in the box at the top Service right corner of the article or click here.

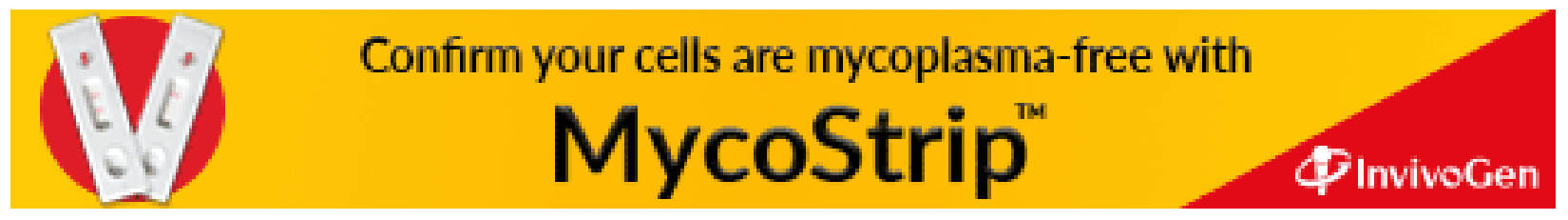

